\title{
Cruise Tourism in Malaysia: a SWOT Analysis
}

\author{
K. L, Chong \\ Centre for Tourism, Hospitality and Culinary Management, Sunway University, \\ Bandar Sunway, Petaling Jaya, Malaysia
}

ABSTRACT: According to Tourism Malaysia, the Asian and international cruise in growing at the average of $14 \%$ annually over the past ten years while number of cruise passengers in Malaysia also expected to exceed half a million in 2013. Despite its potential, the cruise industry in Malaysia is facing ever-growing of competitions from their neighboring countries. An SWOT Analysis was used to discuss the potential of improving strategic decision and planning for cruise tourism in Malaysia. According to findings, notable strengths include a growing market and the government's push to upgrade ports' infrastructure. Weaknesses include oligopolistic competition and negative perception of Malaysian cruises being overly gamblingoriented rather than holiday making. Opportunities are seen in three areas: 1) Increase of spending in travel and cruising; 2) Exemption from the Malaysia Cabotage Policy was given to all international cruises by the Malaysian government, hence, attracting more international cruises to stopover to more destinations in Malaysia; 3) Strong supports from Malaysian government, as well as their initiatives to concern, and develop this business now and future. Piracy and safety have been identified as the main threats that create risks for the cruise business in Malaysia.

\section{INTRODUCTION}

According to Tourism Malaysia, the Asian and international cruise in growing at the average of $14 \%$ annually over the past ten years while number of cruise passengers in Malaysia also expected to exceed half a million in 2013 (The Star, 2013). In fact, this is considered as part of the result for Tourism Malaysia to promote cruise tourism of Malaysia actively in several international cruise conferences and exhibitions since 2009 (Tourism Malaysia, 2013).

As the cruise industry in Malaysia is still growing now, there are many challenges that are facing in this sector. Although this business is growing worldwide yet the Asia Pacific market share is minute and it remains in the product-introduction phase. This trend is unlikely to change anytime soon, as the barriers to entry to the market are increasingly high and many Asian destinations adequate port infrastructure (WTO, 2012).
In order to sustain and obtain benefits from this business, cruise liners need to work together with stakeholders such as governments, port operators, communities and more. Meanwhile, they also should take into consideration on various internal and external factors which might influence the operations or the whole industry. Hence, the purpose of this study aims to discover the internal (strengths and weaknesses) and external factors (opportunities and threats) that are potential in influencing the development and operational decision of cruise tourism or industry in Malaysia.

\section{METHODOLOGY}

SWOT analysis was adopted as a model in assessing the cruise industry of Malaysia. SWOT analysis is not only approach that widely used for reviewing the strategy, position and direction of a particular organization and product yet it is also applicable for any industry (Morrison, 2014). Nevertheless, PESTLE analysis (Political, 
Economy, Social, Technology, Legal and

Environment) was used as an analytical tool in addressing the external environment (Opportunities and Threats) while capability, cultural and organizational analysis was used in assessing the internal environment of the industry (Strengths and Weakness). Latest news, industrial annual reports, statistical reports and reviews pertaining to cruise tourism in Malaysia were the main sources used in the analysis.

\section{FINDINGS}

\subsection{Strengths}

\section{Adequate of Ports and Cruise Infrastructures}

Ports and cruise infrastructures are playing a very significant role in the cruise industry as their relationship is like a complementary product for each other (World Cruise Industry Review, 2013; Manning, 2006). One of the strengths for a cruise industry in Malaysia is that the government has significantly invested in the development of ports and cruise infrastructures for embarkations and disembarkations in the. According to Kevin Leong (2013), general manager for Asian Cruise Association (ACA), developments on this area have significantly attracted more and more cruise liners to venture into a particular country or region. For instance, there are a total of six main ports that are strategically and adequately located in Malaysia for cruise's stopover which including Port Klang, Penang, Malacca, Kuching, Kota Kinabalu, and Langkawi (ETP, 2012). Indeed, Malaysian government also eventually increased the cruise ship capacity of Port Klang in order to cater to larger ships and more passengers as part of the Entry Points Project (EPP) six which focusing in cruise tourism (The Star, 2013; ETP, 2012). reason that South-East Asia is having more than 25,000 islands within the region that provide a natural strength for this area in the international cruise industry. Eventually, Malaysia will be able to gain advantage from this region's growing cruise market as it is geographically located in South-East Asia (The Star, 2013). Furthermore, this area also allowed the industry to access to markets that comprised of $60 \%-70 \%$ of the world population (AKIT, 2012).

\section{Award Winning Ports and Cruise Operators}

Reorganization towards the cruise industry in Malaysia is gained through the world class awards that received by both the cruise terminals and local cruise operators such as Star Cruises. For instance, Star Cruises Terminal in Port Klang and Jetty Terminal in Langkawi Island Malaysia were proudly awarded the Statements of Compliance under the International Ship and Port Facility Security (ISPS) Code 2002 (Genting Group, 2014; UC Cruises, 2014). This code is primarily a security threat preventive framework which involves several parties including cooperation and contracting governments, government agencies, local authorities and members of the shipping and port fraternity.

In terms of the local cruise operators, Star Cruises is also well recognized for its world class service standards of hospitality not only in the cruise industry of Malaysia but the whole Asia Pacific (UC Cruises, 2014). These international recognized awards would then play a significant role and act as the strength of the cruise industry in Malaysia as it is not only a testimonial towards the cruise facilities and cruise service standards but also strengthen the positive impression and perception towards Malaysia's cruise industry.

\section{Strategic Location of Malaysia}

Location of Malaysia is strategically considered as a cruise destination. Indeed, this is due to the 


\subsection{Weaknesses}

\section{Market Structure of Cruise Industry - Oligopoly}

The seven major cruise operators who dominated the whole cruise industry now are owned by only three corporations who overall controlled nearly $80 \%$ of the whole cruise market (Wood, 2004; Lekakou et al., 2009). Carnival Cruise Lines, Costa Cruises, Holland America, Aida Cruises, Cunard Line, Ocean Village, P\&O Cruises, Seabourn Cruise Line, Windstar Cruises and Princess Cruises are all owned by Carnival Corporation (World's Leading Cruise Lines, 2014); Celebrity Cruises, Pullmantur, Azamara Cruises, Croisieres de France (CDF) and Royal Caribbean International are owned by Royal Caribbean (Royal Caribbean International, 2014); while Star Cruises Group of Malaysia also owns NCL America, Norwegian Cruise Line, Orient Lines as well as Star Cruises (Star Cruises, 2014; NCL, 2014).

The barrier of new entry into this cruise business market is high as it is dominated just by these three conglomerates. Besides, the products and services provided by the cruise liners in this market would be very homogenous as the competition is not high. The development of the cruise industry either in Malaysia or internationally might be constrained by having a very homogenous products and services in the market.

\section{Gambling versus Muslim}

In an Islamic country like Malaysia, gambling is an illegal activity for the Muslims and even strict rules and regulations are imposed to the very limited number of licensed casinos that available in the country. However, Clarke (1999) found that casinos or gambling facilities are not only an onboard activity that enlightens the cruise passengers but it also plays a significant role in the cruise industry as a major profit contributor in their annual profit and loss reports. Furthermore, it is also not uncommon for cruise operators to set up a casino or provide gambling facilities onboard as casino that is operating offshore or on international sea is not regulated by legislation or government (Ng \& Kwortnik, 2007).

Hence, it can be seen as a weakness for the cruise industry in Malaysia when the cruise liners start to concern and focus on the gambling activities and forgetting the importance of the Muslims market in Malaysia as they are the biggest population in Malaysia yet are illegal to gamble according to the law.

\section{Labour Shortage}

Although the cruise industry is well-known for its globalised workforces onboard yet labour shortage has become one of their weaknesses that might harm the cruise liners or even the cruise industry itself (Gibson, 2008; Terry, 2011; Larsen et al., 2012). Burke (2009) had identified that mistreat of cruise employees is part of the labour issues that lead to labour shortages in this industry as cruise liners will have a chance to escape from labour laws when they registered their cruises and company in foreign countries.

Additionally, Larsen et al. (2012) also reveal that jobs onboard is considered as very isolated as compared to others whereby the employees have no choice, but to be cut off from any recreational activities, their own families and friends. Indeed, low work engagement, job autonomy and departmental resources will lead to low employee retention.

\subsection{Opportunities}

\section{Increase of Spending in Travel and Cruising} As reported in the study done by Travel Weekly (2012), 43\% of consumers are expected to spend significantly more while $31 \%$ spend somewhat more for travelling. This economy factor is 
considered as one of the opportunities for cruise tourism in Malaysia to boost as this situation will enable more people around the world to travel with cruises as their spending on travel is increasing. Despite international market, the cruise industry of Malaysia also might be benefits from its domestic market as $73 \%$ of Malaysian indicated that they would increase their budget for travelling in 2013 in the research done by Trip Advisor (The Star, 2013).

According to Travel Weekly (2012), the number of global cruise passengers increased approximately two million (10\%) as the figures increased from 18.7 million in 2010 to 20.6 million for 2011. In terms of Asia and Pacific region, its total number of cruise passengers goes up to almost 800,000 which contributed a $6 \%$ market share with a combined growth rate of $90 \%$ from year 2001 to 2004 (WTO, 2012). Hence, these evidences strongly shown that people were not only spent more in travelling but there is an increasing trend for cruising.

\section{Relieved from Cabotage Policies}

In Malaysia, Cabotage Policy was initially implemented with the main objective to improve Malaysian ownership and local shipping as well as to control the dependence of Malaysia on foreign vessels that lead to the outflow of foreign exchange (Malaysiakini, 2009).

However, it is an opportunity for the cruise industry of Malaysia whereby an exemption from the Malaysia Cabotage Policy was given to all international cruises by the Malaysian government (ETP, 2012). By having this opportunity to be exempted from this government policy, international cruises are now allowed to disembark and re-embark cruise passengers at more than one Malaysian port in any of its stopover destinations throughout the itinerary (ETP, 2012; Malaysiakini, 2009). In return, this will helps to develop the cruise industry in Malaysia by attracting more international cruises to stopover to more destinations in Malaysia.

\section{Government Supports and Initiatives}

Cruise industry is part of the high impact project of Malaysia, which is the Economy Transformation Programme (ETP) that introduced and launched in year 2010 (ETP, 2012). Thus, cruise industry in Malaysia is being considered as one of the national key economic areas by the government.

Furthermore, a policy-making public-private stakeholders' advisory committee were also formed under this programme with the function of providing direction for policies, developments and frameworks required by the cruise industry in Malaysia (ETP, 2012). In fact, this advisory committee is known as The Malaysia Cruise Council (MCC) whereby another six sub-task forces were also formed underneath to address and streamline the specific issues of those six identified ports in Malaysia (ETP, 2012).

\section{Free from Severe Natural Disaster}

The fact that Malaysia is free from any severe natural disaster such as Tsunami, earthquakes, typhoons and volcanic eruptions since it is strategically located out of the "Pacific Rim of Fire" (Disaster Management Division of Malaysia, 2011). This is an opportunity to promote and develop Malaysia as an international cruise destination because the safety issues of a particular country or destination is basically a main concern and consideration when choosing a cruise destination either by the cruise operators or cruise passengers (Manning, 2006; London, 2011). This is also justified by the research done Travel Canada (2014) who found that $87 \%$ of the target respondent (cruise passengers) revealed that the safety issue is definitely their main concern for cruising. 


\subsection{Threats}

\section{Negative Perceptions towards Cruising}

One of the most common negative perceptions towards cruise tourism would be the safety issues of the cruises due to the emergent of cruise incidents recently. In fact, these cruise incidents have negatively impacted on the demand for cruise tourism as well as the prices for the cruise tour. For instance, the demand for cruise tourism was found approximately $15 \%$ to $20 \%$ in the weeks after the cruise incident of Costa Concordia that stranded off the coast of Isola del Giglio, Italy on 13th of January 2014 (CBC News, 2012).

Another negative perception towards cruising will be misperception of the customer whom portrait cruises as a cheap and gambling focus excursion, especially for the Asian market (Golden, 2013). Asian always have the conservative thought that assumed onboard casino as the main attraction that commonly used to promote a particular cruise or cruise liner yet this is not the case.

\section{Piracy}

Externally, piracy also has been identified as one of the threats that create risks for a cruise industry (Dowling, 2006; Global Travel Industry News, 2009; Bundhun, 2011). According to a report presented by Statista (2013), the statistic of pirate attacks was the highest in year 2010 recorded 445 cases. Although the number of pirate attacks reduced to 297 in year 2012 yet it does create a threat towards the safety of the cruise industry (Dowling, 2006).

Indeed, the primary routes of international cruising as well as the geographical location of piracy include the Indian Ocean, Straits of Malacca, Red Sea or Horn of Africa, and Indonesian and Malaysian waters which contributed to the areas of concern in the cruise industry (Global Travel Industry News, 2009; Dowling, 2006). This factor will then take into consideration of the cruise liners when designing on the itinerary of the cruises as well as when consider a cruise destination due to the reason that passenger safety and security are always the primary concerns of them, says Sasso as the chairman of the Cruise Lines International Association (CLIA) in the Global Travel Industry News (2009).

\section{CONCLUSION}

In overall, there are several great opportunities that can be ride on using the strengths that are currently available in the industry or market. On the other hand, the government and cruise operators should also take into consideration of overcoming the threats that posed by the environment and the industry itself. It is very crucial for all the stakeholders and shareholders of the cruise industry in Malaysia to work together for future development and sustainability.

In terms of threats such as the negative perception, threats of substitute tourism products and piracy, the government might look into the reinforcement of government policy regarding the safety and security of Malaysian waters in order to minimise or avoid from severe piracy. Moreover, the cruise liners may try to improve on the perceptions of people towards cruising in Malaysia or other regions. Perhaps, this can be done through educating the public or market with more specific knowledge about cruising or through a properly plan media and social network as the societies now are much influenced by the media and social networks in their daily life.

All in all, there are rooms for the cruise industry in Malaysia to further develop and sustain in the industry. However, this is only provided when the cruise operators, port authorities, communities, and the government are to work together in planning and strategy developments. 


\section{References}

AIPA. (2011) "Brief Note on The Roles of the National Security Council, Prime Minister's Department as National Disaster Management Organization (NDMO)". 3rd AIPA CAUCUS REPORT. [report] pp. 1-13.

Bundhun, R. (2011) "Gulf cruises under threat from pirates | The National”. [online]

Burke, C. (2009) "A Qualitative Study of Victimization and Legal Issues Relevant to Cruise Ships”.

CBC News. (2012) "Cruise ship incidents drive down demand, prices - World - CBC News”. [online]

Clarke, J. (1999) “Cruise lines just say no”. [online]

Dowling, R. (2014) “Cruise Ship Tourism”. India: CABI Publisher.

Genting. (2014) “Group Profile - Star Cruises Limited”. [online]

Gibson, P. (2008) "Cruising in the 21st century: Who works while others play?”. International Journal of Hospitality Management, 27 (1), pp. 42-52.

Global Travel Industry News. (2009) “Cruise Industry Vs. Piracy Cruise lines weigh tougher response to pirate threat near Somalia "[online]

Golden, F. (2013) "Cracking Challenging Asia Cruise Market Is No Slam-Dunk”. [online]

Larsen, S., Marnburg, E. and Øgaard, T. (2012) "Working onboard - Job perception, organizational commitment and job satisfaction in the cruise sector". Tourism Management, 33 (3), pp. 592-597.

Lekakou, M., Pallis, A. and Vaggelas, G. (2009). "Is This A Home-Port? An Analysis Of The Cruise Industry's Selection", paper presented at International Association of Maritime Economists (IAME) Conference, Copenhagen, Denmark, 24-26 June.

London, W. R. (2011) "Economic risk in the cruise sector". (18).

Malaysiakini. (2009) “Cabotage policy will be reviewed”. [online]

Manning, T. (2006) "Managing Cruise Ship Impacts:

Guidelines for Current and Potential Destination

Communities". [online]

Morrison, M. (2014) "SWOT Analysis - History, Definition, Templates \& Worksheets |RAPIDBI”. [online]

Ng, I. and Kwortnik, R. J. (2007) "Balancing Cruise Revenue Sources: The Case of Empress Cruise Lines". Case Research Journal, 27 (2), pp. 105-127.

NLC. (2014) "Our Family \& Star Cruises | NCL Cruise

Family | Norwegian Cruise Line”. [online]
Royal Caribbean International (2014) "Investor relation". [online]

Statista (2013) "Cruise passenger share source market worldwide 2013 | Statistic”. [online]

Terry, W. C. (2011) “Geographic limits to global labor market flexibility: The human resources paradox of the cruise industry". Geoforum, 42 (6), pp. 660-670.

The Star (2013) "Smooth sailing for cruise industry Malaysia” | The Star Online. [online]

The Star (2013) "Malaysians to spend more on holidays Nation "| The Star Online. [online]

Tourism Malaysia. (2012). "ETP Annual Report 2012.

NKEA": Tourism. [report] Malaysia: pp. 118-139.

Travel Canada (2014) "Most Popular Cruise Destinations”. [online]

Travel Weekly (2012) “Global cruise passengers top 20 million”. [online]

UC cruises (2014) "UCCRUISES.COM" - Powered By Unique Choice. [online]

UNWTO (2012) “Asia-Pacific Newsletter”. [online]

Wood, R. E. (2004) "Neoliberal Globalization: The Cruise Ship Industry as a Paradigmatic Case".

World Cruise Industry Review. (2013) “Untapped potential World Cruise Industry Review”. [online]

World's Leading Cruise Lines (2014) "Find a Cruise \& Compare Cruises”| WorldsLeadingCruiseLines.com. [online] 